\title{
Vessel Common Origin
}

National Cancer Institute

\section{Source}

National Cancer Institute. Vessel Common Origin. NCI Thesaurus. Code C124516.

A finding that the blood vessels are arising from the same location. 